\section{Scientific journal}

\section{PHYSICAL AND MATHEMATICAL EDUCATION}

Has been issued since 2013.

Науковий журнал

ФІЗИКО-МАТЕМАТИЧНА ОСВІТА

Видається з 2013.
ISSN 2413-158X (online)

ISSN 2413-1571 (print)

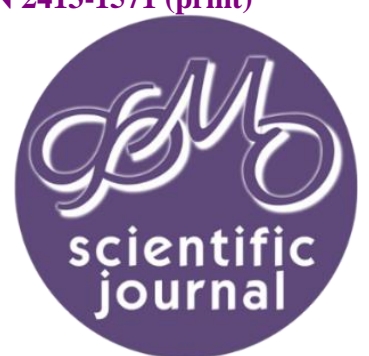

Набока О.Г., Татьянчикова І.В. Спеціальна освіта: сучасні підходи до підготовки фахівців для навчання дітей $з$ особливими освітніми потребами. Фізико-математична освіта. 2021. Випуск 1(27). С. 76-81.

Naboka O., Tatianchikova I. Special education: modern approaches to training specialists children with special educational needs. Physical and Mathematical Education. 2021. Issue 1(27). P. 76-81.

DOI 10.31110/2413-1571-2021-027-1-012

удк 376.09

О.г. Набока

ДВНЗ «Донбаський державний педагогічний університет», Україна olganaboka911@gmail.com ORCID: 0000-0003-4635-0009

І.В. Татьянчикова

ДВНЗ «Донбаський державний педагогічний університет», Україно

i.tatyanchikova@gmail.com ORCID: 0000-000-2-9526-9672

\title{
СПЕЦІАЛЬНА ОСВІТА: СУЧАСНІ ПІДХОДИ ДО ПІДГОТОВКИ ФАХІВЦІВ ДЛЯ НАВЧАННЯ ДІТЕЙ З ОСОБЛИВИМИ ОСВІТНІМИ ПОТРЕБАМИ
}

АНОТАЦІЯ

Формулювання проблеми. У статті розкрито сучасні підходи до фрахової підготовки фахівців для навчання дітей з особливими освітніми потребами. Зазначено, що в умовах соціально-економічних змін у суспільстві, нових поглядів на якість освіти в цілому, назріла необхідність реформування і осучаснення основних положень спеціальної освіти, що вимагає ії відповідності європейським і новим Державним стандартам в Україні.

Матеріали і методи. Для визначення сучасних підходів з підготовки фахівців для навчання дітей з особливими освітніми потребами у дослідження були використання теоретичні методи: аналіз, узагальнення, інтерпретація сучасної наукової та навчально-методичної літератури.

Результати. Результати обгрунтовують необхідність здійснення системної, поступової та послідовної спеціальної педагогічної роботи, яка спрямована на розвиток соціальної активності, виховання життєздатності особистості через формування у неї життєвих компетентностей, що забезпечить спроможність повноцінного існування дитини з особливими освітніми потребами у соціумі. Визначено основні складові нової Концепції спеціальної освіти: інклюзивна форма навчання дітей з особливими потребами, забезпечення їхньої соціалізації, особистісно-зорієнтований та компетентнісний підходи. Основну увагу зосереджено на низці проблем, які є й досі не вирішеними і гальмують процес підготовки фахівців для навчання дітей з особливими освітніми потребами, у тому числі й в інклюзивному закладі освіти.

Висновки. За результатами теоретичного дослідження доведено необхідність проведення підготовки фрахівців для реабілітації дітей у широкому сенсі. Висвітлено ідею незалежного життя, яка є ядром сучасної Концепції спеціальної освіти. Наголошуються, що фахівці спеціальних навчальних закладів мають відігравати важливу роль в керуванні процесом соціального розвитку своїх вихованців і досягненні ними загального рівня соціальної переконливості. Зазначено на необхідності упровадження інноваційних підходів до підготовки фахівців для навчання дітей з особливими потребами.

КЛЮчОВІ СЛОВА: спеціальна освіта, діти з особливими освітніми потребами, Нова філософія освіти, нова Концепція спеціальної педагогіки, інклюзивна освіта, соціалізація, особистісно-зорієнтований підхід.

ВСТУП

Постановка проблеми. Виклики сьогодення щодо сучасної освіти, які спрямовано на досягнення нової якості навчання підростаючого покоління, а в цілому - нової якості життя, мають свій сенс і свою філософію.

Саме тому на часі й реформування і осучаснення спеціальної освіти, що вимагає їі відповідності європейським та суспільним викликам, одним з яких $є$ забезпечення рівного доступу дітям з особливими потребами до якісної освіти втілення їх можливостей до повноцінного існування у соціумі. 
Запровадження інклюзивної форми навчання, підвищення вимог до рівня і якості корекційно-виховної роботи у спеціальних школах в контексті сучасних досліджень науки та започаткування освітньої реформи у країні, спонукає поновому розв'язувати й питання зміцнення якості навчання і виховання дітей з особливими потребами. Саме тому ці процеси потребують переосмислення, оновлення, аналізу і удосконалення. Новий рівень, на який виходить спеціальна загальноосвітня школа, визначає необхідність розроблення нової концепції, нових освітніх стандартів, узагальнення наявних теоретичних положень для підготовки фахівців нової формації. Перехід спеціальних закладів освіти на нові програми спонукають педагогів забезпечити систематичну і стабільну роботу, спрямовану на різнобічне виховання дітей з особливими потребами, простежити динаміку становлення їхніх особистісних якостей, теоретично усвідомити сучасні підходи до навчання, проаналізувати отримані результати.

Практика свідчить, що діти цієї категорії часто стикаються з певними серйозними проблемами, які самостійно розв'язати не в змозі. Вони потребують ретельної уваги і суттєвої допомоги з боку кваліфікованих спеціалістів: корекційних і соціальних педагогів, психологів.

Сьогодення поставило гостре питання підготовки фахівців спеціальної освіти: або вона і далі буде розвиватися у напрямі традиційних понять, підходів до дітей з особливими освітніми потребами як пасивних об'єктів впливу, недооцінки їх духовного становлення і розвитку, або наповнить новим, життєтворчим змістом навчання і виховання, задекларувавши, що головне для спеціальної, у тому числі й інклюзивної, освіти - дитина, з ї̈ радощами і болями, різними проблемами, потребами, інтересами, з їі особистим внутрішнім світом.

На сучасному етапі розвитку суспільства, як ніколи, гостро постало завдання переосмислення та пізнання буття, створення нової філософії освіти, спрямованої на розкриття життєвого потенціалу дитини. На цій основі і повинна формуватись нова педагогіка - педагогіка компетентної, відповідальної людини. Це спонукає до пошуку нових ідей, сучасних методів і прийомів роботи, започаткованих на інноваційній основі. Нова українська школа у цьому контексті стає загальноосвітнім навчальним закладом цілісного і успішного розвитку та саморозвитку дитини як творця своєї долі, свого життя. Головна функція педагога - навчити дитину використовувати набуті знання в процесі практичного життя і професійної діяльності. Інноваційна модель розвитку освіти потребує виховання цілісної особистості, здатної до самостійного і ефективного існування у соціумі. У цьому контексті особливого значення набуває необхідність розроблення нових підходів до підготовки фахівців для навчання дітей з особливими потребами, яка буде сприяти досягненню нової якості освіти.

Спеціальна освіта гостро потребує перегляду i переосмислення парадигми освітньо-реабілітаційного i корекційного процесу, оновлення його змісту і впровадження сучасних, у тому числі й інформаційних, технологій. Ключовим принципом нової стратегії є розуміння того, що діти з особливими потребами повинні не пристосовуватись до умов суспільства, а активно включатися в його життя як рівноправні громадяни, яким надається відповідна та професійна соціально-педагогічна, психологічна, фінансова допомога та правовий захист. Саме тому важливе завдання спеціальної освіти - сформувати сучасні життєві стратегії, максимально адекватні новій ситуації, яка склалася в українському суспільстві.

Аналіз актуальних досліджень. У нормативних документах (Закон України «Про освіту», 2017р.; «Положення про інклюзивно-ресурсний центр» - Кабінет Міністрів, 2017р.; «Про затвердження порядку організації інклюзивного навчання у закладах вищої освіти» - МОН, 2020р.; «Щодо організації навчання осіб з особливими освітніми потребами у закладах середньої освіти» - МОН, 2020р.), психолого-педагогічній літературі розглянуто різні питання актуальних проблем спеціальної освіти, визначено основні напрями ії реформування, розроблення сучасної Концепції, нових освітніх стандартів, узагальнення наявних теоретичних положень (В.Бондар, О.Глоба, В.Засенко, І.Єрмаков, А.Колупаєва, Г.Лабайчук, Т.Симоненко, В.Синьов) (Глоба, 2016), (Засенко, 2014). Акцентовано увагу на удосконаленні організаційноправових засад забезпечення права на освіту таким дітям, реалізацію їх можливостей і запитів: «Від рівних прав дитини до рівних їх можливостей». Звернуто увагу на впровадження якісної інклюзивної освіти, надання можливості дітям інтегрувати в сучасний освітній простір, розвивати свої здібності в колективі однолітків; особистісно-зорієнтований підхід, в центрі якого розвиток особистості дитини.

Вирішення низки проблем (традиціоналізм, ізоляція дітей від суспільства, соціальні проблеми тощо), які гальмують впровадження інклюзії, процес соціалізації дитини з особливими потребами, розвиток їі особистості, що визначено основними складовими в новій Концепції спеціальної педагогіки, запропоновано у представленій статті.

Мета статті. Визначення сучасних підходів до підготовки фахівців для навчання дітей з особливими освітніми потребами, розкриття шляхів їх реалізації.

\section{МЕТОДИ ДОСЛІДЖЕННЯ}

У дослідження були використання теоретичні методи: аналіз, узагальнення, інтерпретація сучасної наукової та навчально-методичної літератури для визначення сучасних підходів до підготовки фахівців для навчання дітей 3 особливими освітніми потребами.

\section{РЕЗУЛЬТАТИ ДОСЛІДЖЕННЯ}

Навчання і виховання осіб з особливими потребами пройшло довгий і складний еволюційний шлях: від їх пригнічення, повного ізолювання - до сучасного стану спеціальної педагогіки, визнання таких людей повноцінними членами суспільства і надання їм можливості створення власної долі. Втім, на сучасному етапі, в процесі навчання і виховання осіб з інвалідністю, виникають певні і суттєві проблеми, які необхідно вирішувати засобами спеціальної освіти:

а) соціальні проблеми (недостатність форм соціальної підтримки, обмеженість охорони здоров'я, освіти, побутового обслуговування, відсутність належних допоміжних засобів для існування цих осіб в оточуючому середовищі: пантузів, спеціальних доріжок для пересування тощо); 
б) традиціоналізм (застарілі погляди на дитину з особливими потребами, орієнтація в процесі професійного навчання на звичні для неї професії: слюсар, тесляр, швачка, муляр тощо);

в) недостатня профілактика (необхідність залучення спеціалістів різних профілів: психоневрологів, інших медиків, педагогів, психологів, соціальних педагогів, соціологів, а також - батьків);

г) ізоляція дитини від суспільства (необхідність і шляхи запровадження інклюзивної форми навчання);

д) недостатня реабілітація дитини (необхідно запровадити: розвиток духовних та фізичних здібностей дитини; отримання нею відповідної освіти; забезпечення умов для повноцінного життя в суспільстві; розуміння дитиною своїх власних перспектив: індивідуальних особливостей, психофізичних можливостей, нахилів та інтересів; сприяння виконанню нею певної діяльності; постійна підтримка дитини; організація ії дозвілля; охоплення реабілітаційним процесом не тільки дитини, а й ї̈ найближчого оточення).

Отже, освітньо-реабілітаційний процес має бути спрямований на стратегію побудови розвивального способу життя, виховання вільної й відповідальної особистості.

У цьому контексті, у новій Концепції спеціальної освіти, оговорено сучасні підходи до навчання дітей з особливими потребами: акцент переноситься на впровадження інклюзії, забезпечення соціалізації дітей цієї категорії, особистіснозорієнтований та компетентнісний підходи.

Розглянемо кожну зі складових нової Концепції спеціальної освіти.

Реформування і модернізація освіти, які відбуваються в умовах суспільних трансформацій, вимагають ії відповідності цивілізаційним викликам, одним з яких $є$ забезпечення доступу до загальноосвітнього простору і якісної освіти дітям з особливими потребами. Зважаючи на це, осучаснення освіти в Україні на сьогодні пов'язують із задоволенням інтересів і потенційних можливостей розвитку особистості кожного громадянина суспільства, у тому числі й з інвалідністю, в умовах інклюзивного освітнього середовища. Відтак, останнім часом питання інклюзивної освіти набувають вагомої значущості, що яскраво презентовано у гаслі: «Інклюзивна освіта - рівень свідомості нації».

«Під інклюзивним освітнім процесом розуміємо залучення дитини з особливими потребами до навчального середовища за місцем проживання із цілковитим забезпеченням відповідної корекції порушень розвитку з метою максимального включення дитини у соціальне середовище відповідно до правового підходу до розуміння інвалідності та особливих потреб загалом» (Ферт, 2020). При цьому інклюзивний освітній процес повинен бути корекційно спрямованим, доступним, науково обґрунтованим та центрованим не лише на дитині, а й на їі родині, оскільки батьки $€$ партнерами і учасниками навчально-виховного процесу. Особливого значення набувають індивідуальний та диференційований підхід в процесі складання індивідуальної програми розвитку кожної дитини.

Впровадження інклюзивної освіти $€$ достатньо тривалим, відповідальним і складним інтелектуальноорганізаційним процесом, який вимагає виважених рішень, наукових розвідок у різних сферах і дотримання основоположних прав людини.

Крім позитивних тенденцій, впровадження інклюзивної освіти стикається з невирішеністю низки проблем державного рівня:

- сформульовані в освітніх стандартах предметні компетенції майбутніх психолого-педагогічних кадрів недостатньо забезпечують підґрунтя для викладання в умовах інклюзивного освітнього середовища (IOC);

- відсутність особистісної вмотивованості педагогів для участі в інклюзивних процесах;

- недостатність теоретичної й практичної підготовки педагогів для реалізації власного потенціалу при роботі 3 дітьми з особливими освітніми потребами у закладах з інклюзивною формою навчання;

- неусвідомленість значення командної діяльності в умовах IOC;

- необхідність розроблення теоретичної моделі формування професійної компетентності випускника закладу вищої педагогічної освіти, спроможного працювати в умовах IOC;

- недостатня увага центральних і місцевих органів державної виконавчої влади та органів місцевого самоврядування до забезпечення прав дітей з інвалідністю на якісну освіту;

- відсутність єдиної державної політики щодо педагогічного, медичного та соціального супроводу особи $з$ інвалідністю впродовж усього життя, у тому числі й щодо впровадження інклюзивного навчання;

- недостатній рівень надання корекційно-реабілітаційної допомоги дітям з особливими потребами, які навчаються в інклюзивних групах (класах) у закладах дошкільної та загальної середньої освіти;

- недостатня кількість кваліфікованих педагогічних, медичних та соціальних працівників, спеціальних педагогів і психологів для роботи з дітьми в мовах ІОС;

- недостатнє фінансування інклюзивної освіти: виникає проблема недостатнього матеріально-технічного, навчально-методичного та кадрового забезпечення закладів освіти;

- відсутність відповідного середовища, адаптованого для навчання цих дітей, недотримання санітарних норм експлуатації архітектурних споруд, де навчаються діти;

- недостатня готовність українського суспільства до сприйняття дітей з особливими потребами як повноправних членів учнівського колективу у закладах дошкільної та загальної середньої освіти (Мартинчук, 2018).

Наступною важливою складовою нової Концепції спеціальної освіти $є$ успішна соціалізація дітей з особливими потребами.

Соціалізація визначається як процес формування особистості у певних соціальних умовах, а також процес засвоєння індивідом соціального досвіду, у ході якого він перетворює соціальний досвід у власні цінності та орієнтації, вибірково залучає до своєї системи поведінки ті норми і шаблони, які прийняті у суспільстві (Столяренко, 2001). Процес соціалізації відбувається у певних сферах: діяльність, самосвідомість, спілкування та поділяється на основні стадії:

- первинну соціалізацію, або стадію адаптації (від народження до підліткового віку), продовж якої дитина засвоює соціальний досвід і соціальні норми поведінки; 
- стадію індивідуалізації (підлітковий вік), на якій у дитини з'являється бажання виділити себе серед інших, критичне ставлення до суспільних норм поведінки;

- стадію інтеграції (підлітковий і юнацький вік), на якій у дитини з'являється бажання знайти своє місце в суспільстві, тобто вписатися в навколишнє середовище;

- трудову стадію (весь період зрілості людини, їі трудової діяльності).

В умовах спеціального (інклюзивного) закладу освіти дитина проходить вище зазначені стадії (трудова стадія визначається як стадія ранньої трудової підготовки). Практика свідчить, що діти з особливими потребами часто стикаються з певними серйозними проблемами в процесі соціального становлення і потребують фахової допомоги. Саме спеціальний заклад освіти, а також заклад з інклюзивною формою навчання, стає основною ланкою цілеспрямованої соціалізації учнів. Педагогічний колектив має «запустити» механізм самоорганізації та саморозвитку дитини з тим, щоб нею був набраний соціальний потенціал, який і визначить в подальшому масштаби світу, в якому вона зможе повноцінно існувати (Татьянчикова, 2017).

Отже, для школи принципово необхідним стає взаємодія і співпраця педагогів-професіоналів, які розуміють важливість і сутність соціалізації учнів. Саме тому назріла гостра необхідність оволодіння педагогами основами теоретичних і практичних знань щодо забезпечення соціалізації дітей з особливими потребами.

В основу оновленого змісту освіти для дітей з особливими потребами та Державного стандарту загальної освіти покладено особистісно-зорієнтований та компетентнісний підходи.

Особистісно-зорієнтований підхід конкретизує академічний компонент освіти через встановлення відповідності засвоєння дітьми з особливими освітніми потребами академічних знань та формування компетенцій і компетентностей в умовах корекційної спрямованості навчання та виховання. Академічні знання, вміння та навички корелюють зі сформованою у дітей здатністю їх реалізації у житті для досягнення мети, що й визначає життєву компетенцію, тобто у межах можливостей кожної дитини здійснюється підготовка до їі активного життя в сім'ї та соціумі.

Компетентнісний підхід визначає спрямованість навчально-виховного процесу на досягнення результатів, якими $\epsilon$ ключові, загальнопредметні, предметні та життєві компетентності (Набока, Давискиба, 2019) без яких неможлива діяльність сучасної людини в інтелектуальній, суспільно-політичній, комунікаційній, інформаційній та інших сферах. Компетентнісна парадигма націлена на посилення практичної орієнтації освіти, прагне підготувати людину умілу та мобільну, котра володіє не набором фактів, а способами та технологіями їх отримання. Особливого значення у цьому контексті набувають життєві компетентності - здатність дитини інтегрувати у соціальне середовище, тобто цілісно реалізувати на практиці знання, досвід і цінності, набуті у процесі корекційного навчання та виховання через оновлення змісту освіти.

Перехід до компетентнісно спрямованої освіти обумовлює потребу переосмислення фундаментальних концептуальних засад змісту спеціальної освіти. При цьому дуже важливим стає забезпечення якості освіти. Можна визначити основні умови забезпечення цього процесу (Синьов, 2010):

- єдність корекційного впливу на зміст свідомості, діяльнісні та особистісні характеристики інтелекту дитини;

- єдність забезпечення адаптації засобів педагогічного процесу до особливостей інтелектуального розвитку учнів, спрямованість цих засобів на максимально можливий розвиток здатності засвоювати людську культуру впродовж всього подальшого життя;

- освітній процес має бути спрямований на формування в учнів вищих психічних функцій, головні ознаки яких усвідомленість і довільність;

- єдність у навчальному процесі засвоєння знань та їх застосування;

- формування продуктивного мислення, творчості, активності у вирішенні різноманітних пізнавальних завдань, серед яких центральне місце посідають завдання на розкриття причинно-наслідкових зв'язків у освітній інформації та діяльності;

- педагогічна орієнтація на поступовий розвиток пізнавальної самостійності учнів, перманентного переводу потенцій із зони найближчого розвитку учня на рівень його актуального розвитку;

- забезпечення учневі з порушеннями розвитку успіху в навчальній діяльності, спеціального закріплення позитивних новоутворень у особистості;

- перспективне моделювання особистості учня, його післяшкільної адаптації, особливостей соціалізації у різних сферах (Синоьв, 2018).

\section{ОБГОВОРЕННЯ}

Незважаючи на значні досягнення в галузі спеціальної світи в сучасній Україні, залишаються ще не вирішеними багато проблем, які $є$ дуже гострими і потребують системного розгляду. Це питання щодо:

- які освітні та корекційно-реабілітаційні умови: диференційовані чи інтегровані, $є$ найбільш ефективними для соціалізації осіб з особливими потребами;

- як найкраще об'єднати зусилля представників різних наук (медицини, психології, педагогіки, соціології) для надання комплексно-системної освітньо-реабілітаційної допомоги дітям з особливими потребами та їх родинам;

- як забезпечити толерантне, гуманістично-дійове ставлення суспільства до осіб цієї категорії;

- які методологічні та теоретичні засади $€$ найбільш перспективними для розроблення продуктивних технологій корекційного навчання, виховання і розвитку людини з обмеженими можливостями на різних вікових етапах соціалізації;

- як подолати екологічні труднощі, недосконалість юридично-правової бази щодо визначення гарантій загальнолюдських прав людини з особливими потребами. 


\section{ВИСНОВКИ ТА ПЕРСПЕКТИВИ ПОДАЛЬШОГО ДОСЛІДЖЕННЯ}

Спеціальна вища освіта має запропонувати фахівців, які володіють сучасними соціально-реабілітаційними технологіями з урахуванням основних напрямів: гуманістичного, діяльнісного, інноваційного. Така парадигма змінює традиційний підхід до розуміння тріади “дитина - суспільство - держава». 3 огляду на це, основна мета навчання дитини з особливими потребами - сприяння покращенню ії якості життя, захист ії інтересів у різних сферах життєдіяльності, створення умов для вирівнювання і розвитку їі можливостей, що є передумовою незалежного життя.

Отже, ідея незалежного життя людини з особливими потребами є ядром сучасної Концепції спеціальної освіти, якою мають керуватися спеціальні заклади освіти, у тому числі й заклади вищої освіти при підготовки фахівців для навчання дітей з особливими освітніми потребами. Відтак, мають суттєве значення наступні слова: «Спеціалісти не повинні приймати розповсюджені думки некритично. Треба пропонувати нові теорії, заперечувати старі погляди, збирати нові дані, і це дасть можливість удосконалити чи навіть витіснити зроблене раніше» (американські автори Е. Зіглер та Р. Ходапп) (Татьянчикова, 457).

\section{Список використаних джерел}

1. Глоба О.П. Про національну систему надання корекційно-реабілітаційних послуг в Україні. Інклюзивна освіта: досвід і перспективи: монографія / відп. ред. Г.В. Давиденко. Вінниця: ТОВ «Нілан-лтД», 2016. С.

2. Засенко В. В., Колупаєва А. А. Діти з особливими потребами: пріоритетні напрями державної політики України в галузі освіти, соціального захисту й охорони здоров’я. Дефектологія. Особлива дитина: навчання і виховання. 2014. № 3. C. 20-29.

3. Мартинчук О.В. Підготовка фахівців зі спеціальної освіти до професійної діяльності в інклюзивному освітньому середовищі: монографрія. Київ: Центр учбової літератури, 2018. 430с.

4. Набока О.Г., Давискиба В.О. Проблеми і перспективи застосування компетентнісного підходу у професійній освіті. Гуманізація навчально-виховного процесу. 2019. №5(97). С. 167-170.

5. Синьов В.М. Методологія та теорія досліджень в галузі дефектології. Збірник наукових праць Кам'янець-Поділ. нац. унту ім. Івана Огієнка. Серія «Соціально-педагогічна». Кам'янець-Подільський: Аксіома, 2010. Вип.XV. С. 7-9.

6. Синьов В.М. Нова школа України і проблеми забезпечення якісної освіти дітей з особливостями розвитку. Соціальна $i$ життєва практика дітей з інтелектуальними порушеннями в умовах навчально-реабілітаційних центрів: практико зорієнтований посібник / за ред. І.Г.Єрмакова, К.С.Тороп, К.В.Рейда. Дніпро: «Інновація», 2018. С.26-32.

7. Столяренко Л.Д. Основы психологии. 3-е изд., перераб. и доп. Ростов-на-Дону: Феникс, 2001. 704с.

8. Татьянчикова І. В. Соціалізація дитини з вадами розвитку: теорія, досвід, технології: монографія. Слов'янськ: Видво Б. І. Маторіна, 2017. 457c.

9. Ферт О.Г. Педагогічний супровід дітей із порушеннями психічного розвитку в інклюзивному освітньому процесі. Інноваційна педагогіка. 2020. № 21. С. 73-77.

\section{References}

1. Hloba, O.P. (2016). Pro natsionalnu systemu nadannia korektsiino-reabilitatsiinykh posluh v Ukraini. Inkliuzyvna osvita: dosvid i perspektyvy: monohrafiia [On the national system of correctional and rehabilitation services in Ukraine. Inclusive education: experience and prospects: monograph]. Vinnytsia: TOV «Nilan-LTD [in Ukrainian].

2. Zasenko, V.V., Kolupaieva A. A. (2014). Dity z osoblyvymy potrebamy: priorytetni napriamy derzhavnoi polityky Ukrainy $v$ haluzi osvity, sotsialnoho zakhystu y okhorony zdorovia [Children with special needs: priority directions of the state policy of Ukraine in the field of education, social protection and health care]. Defektolohiia. Osoblyva dytyna: navchannia i vykhovannia - Defectology. Special child: education and upbringing, № 3, 20-29 [in Ukrainian].

3. Martynchuk, O.V. (2018). Pidhotovka fakhivtsiv zi spetsialnoi osvity do profesiinoi diialnosti v inkliuzyvnomu osvitnomu seredovyshchi: monohrafiia [Training of specialists in special education for professional activities in an inclusive educational environment: a monograph]. Kyiv: Tsentr uchbovoi literatury, 430 [in Ukrainian].

4. Naboka, O.H., Davyskyba, V.O. (2019). Problemy i perspektyvy zastosuvannia kompetentnisnoho pidkhodu u profesiinii osviti [Humanization of the educational process]. Humanizatsiia navchalno-vykhovnoho protsesu-Humanization of the educational process, №5(97), 167-170 [in Ukrainian].

5. Synov, V.M. (2010). Metodolohiia ta teoriia doslidzhen $v$ haluzi defektolohii [Methodology and theory of research in the field of special education]. Zbirnyk naukovykh prats Kamianets-Podil. nats. un-tu im.Ivana Ohiienka. Seriia "Sotsialnopedahohichna» - Collection of scientific works Kamyanets-Podil. nat. Ivan Ogienko University. Socio-pedagogical series, Vyp.KhV, 7-9 [in Ukrainian].

6. Synov, V.M. (2018). Sotsialna i zhyttieva praktyka ditei $z$ intelektualnymy porushenniamy $v$ umovakh navchalnoreabilitatsiinykh tsentriv: praktyko zoriientovanyi posibnyk [Social and life practice of children with intellectual disabilities in the conditions of educational and rehabilitation centers: practice-oriented manua ]. Dnipro: «Innovatsiia» [in Ukrainian].

7. Stoliarenko, L.D. (2001). Osnovы psykholohyy. 3-e yzd., pererab. y dop. [Fundamentals of psychology. 3rd ed., Reworked. and ext.]. Rostov-na-Donu: Fenyks [in Ukrainian].

8. Tatianchykova, I. V. (2017). Sotsializatsiia dytyny z vadamy rozvytku: teoriia, dosvid, tekhnolohii: monohrafiia [Socialization of a child with developmental disabilities: theory, experience, technology: a monograph]. Sloviansk: Vyd-vo B.I. Matorina [in Ukrainian].

9. Fert O.H. (2020). Pedahohichnyi suprovid ditei iz porushenniamy psykhichnoho rozvytku v inkliuzyvnomu osvitnomu protsesi [Pedagogical support of children with mental disabilities in an inclusive educational process]. Innovatsiina pedahohika Innovative pedagogy, № 21, 73-77[in Ukrainian]. 


\section{SPECIAL EDUCATION: MODERN APPROACHES TO TRAINING SPECIALISTS \\ CHILDREN WITH SPECIAL EDUCATIONAL NEEDS \\ Olha Naboka, Iryna Tatianchikova}

Abstract. State Higher Educational Institution «Donbas State Pedagogical University», Ukraine

Problem formulation. The article reveals modern approaches to professional training for the education of children with special educational needs. It is noted that in the context of socio-economic changes in society, new views on the quality of education in general, there is a need to reform and modernize the basic provisions of special education, which requires its compliance with European and new state standards in Ukraine.

Materials and methods. To determine modern approaches to the training of specialists for the education of children with special educational needs in the study were the use of theoretical methods: analysis, generalization, interpretation of modern scientific and educational literature.

Results. The results substantiate the need for systematic, gradual and consistent special pedagogical work aimed at developing social activity, educating the viability of the individual through the formation of vital competencies, which will ensure the full existence of a child with special educational needs in society. The main components of the new Concept of special education are identified: inclusive form of education of children with special needs, ensuring their socialization, personality-oriented and competence-based approaches. The focus is on a number of issues that are still unresolved and hamper the training of children with special educational needs, including in an inclusive education institution.

Conclusions. The results of the theoretical study proved the need for training for the rehabilitation of children in a broad sense. The idea of independent living, which is the core of the modern Concept of special education, is highlighted. It is emphasized that specialists of special educational institutions should play an important role in managing the process of social development of their pupils and achieving a general level of social persuasion. The need to introduce innovative approaches to the training of specialists for the education of children with special needs is noted.

Key words: special education, children with special educational needs, New philosophy of education, new Concept of special pedagogy, inclusive education, socialization, personality-oriented approach.

\section{(cc) EY-NG-SA}

This work is licensed under Creative Commons Attribution-NonCommercial-ShareAlike 4.0 International License. 